\title{
Gambaran Darah Penyu Hijau (Chelonia mydas) dengan atau Tanpa Fibropapillomatosis
}

\author{
(BLOOD PROFILES OF GREEN TURTLES (CHELONIA MYDAS) \\ WITH AND WITHOUT FIBROPAPILLOMATOSIS)
}

\author{
Ni Kadek Intan Dwityanti Devi', \\ Ida Bagus Windia Adnyana ${ }^{2}$, I Gede Soma ${ }^{2}$ \\ ${ }^{1}$ Mahasiswa Pendidikan Dokter Hewan, \\ ${ }^{2}$ Laboratorium Patologi Veteriner, ${ }^{3}$ Laboratorium Fisiologi Veteriner \\ Fakultas Kedokteran Hewan Universitas Udayana \\ JL. Sudirman, Sanglah, Denpasar, Bali, Indonesia 80234 \\ Telp. (0361) 255128 Fax (0361) 255128 \\ E-mail: adnyanawindia@gmail.com, \\ intandyd@gmail.com
}

\begin{abstract}
ABSTRAK
Penyu merupakan salah satu hewan yang keberadaannya terancam punah. Di Bali temuan kasus penyelundupan penyu sering terjadi. Beberapa dari penyu yang diselundupkan adalah penyu hijau yang mengalami tumor fibropapillomatosis (FP) yang merupakan tumor yang ditemukan pada semua spesies penyu, tetapi paling banyak ditemukan pada penyu hijau. Fibropapillomatosis ditandai pada bagian tubuh seperti kulit, flippers, jaringan, karapas, dan plastron. Pemeriksaan hematologi menjadi metode diagnostik, dengan melihat adanya kenaikan atau penurunan jumlah sel darah. Penelitian ini bertujuan untuk mengetahui gambaran darah penyu hijau dengan atau tanpa FP. Penelitian ini menggunakan sampel penyu hijau sitaan Kantor Polsek Kuta terdiri dari lima ekor penyu hijau dengan FP dan lima penyu hijau tanpa FP. Pengumpulan data pada penelitian ini dilakukan dengan pemeriksaan hematologi. Sebanyak $3 \mathrm{~mL}$ darah perifer penyu hijau yang diambil dari sinus servikalis dorsalis disimpan dalam tabung heparin untuk dilanjutkan dengan pemeriksaan hematologi. Pemeriksaan hematologi meliputi jumlah eritrosit, nilai hematokrit, dan kadar hemoglobin. Data kuantitatif yang telah diperoleh dianalisis dan dijelaskan secara deskriptif. Hasil pemeriksaan gambaran darah penyu hijau dengan

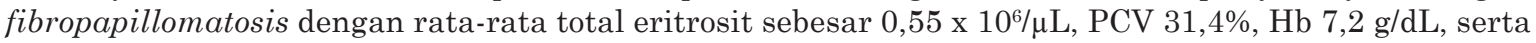
indeks eritrosit, meliputi MCV 616,7 fl, MCH 140,4, MCHC 23,1 g/dL. Gambaran darah penyu hijau tanpa fibropapillomatosis memiliki rata-rata total eritrosit $0,46 \times 10^{6} / \mu \mathrm{L}, \mathrm{PCV} 29 \%, \mathrm{Hb} 7,1 \mathrm{~g} / \mathrm{dL}$, serta indeks eritrosit meliputi MCV 784,7 fl, MCH 191,9 pg, MCHC 24,4 g/dL. Tidak ada perbedaan yang signifikan terhadap gambaran darah penyu hijau dengan atau tanpa fibropapillomatosis. Gambaran darah penyu hijau dengan fibropapillomatosis berada dalam rentang normal.
\end{abstract}

Kata-kata kunci: eritrosit; fibropapillomatosis; gambaran darah; penyu hijau

\begin{abstract}
Sea turtles are one of the animals whose existence is endangered. In Bali, cases of sea turtle smuggling are common. Some of the smuggled turtles are green sea turtles that have fibropapillomatosis (FP) tumors which are tumors found in all turtle species, but most are found in green sea turtles. Fibropapillomatosis is characterized in parts of the body such as skin, flippers, tissues, carapace and plastron. Hematological examination becomes a diagnostic method, by looking at an increase or decrease in the number of blood cells. This study aims to determine the picture of green sea turtle blood with or without FP. This study uses a sample of confiscated green sea turtle Kuta police consisting of 5 green sea turtles with FP and 5 green sea turtles without FP. Data collection in this study was carried out by hematological examination. A total of $3 \mathrm{~mL}$ of green sea turtle peripheral blood taken from the dorsal cervical sinus is stored in a heparin tube to be followed by hematological examination. Hematological examination includes erythrocyte counts, hematocrit values, and hemoglobin levels. Quantitative data that have been obtained are analyzed and
\end{abstract}


explained descriptively. Hematologic examination includes the number of erythrocytes, hemoglobin levels and hematocrit values The data obtained were analyzed by quantitative analysis and explained descriptively. The results of the blood profile of green sea turtle with fibropapillomatosis with an average total erythrocyte of $0.55 \times 10^{6} / \mu \mathrm{L}, \mathrm{PCV} 31.4 \%$, Hb $7.2 \mathrm{~g} / \mathrm{dL}$, and erythrocyte index, including MCV 616.7 $\mathrm{fl}, \mathrm{MCH}$ 140, $4 \mathrm{pg}$, MCHC $23.1 \mathrm{~g} / \mathrm{dL}$. Blood profile of green sea turtle without fibropapillomatosis has an average total erythrocyte $0.46 \times 10^{6} / \mu \mathrm{L}, \mathrm{PCV} 29 \%, \mathrm{Hb} 7.1 \mathrm{~g} / \mathrm{dL}$, and erythrocyte index including MCV $784.7 \mathrm{fl}, \mathrm{MCH} 191,9 \mathrm{pg}, \mathrm{MCHC} 24.4 \mathrm{~g} / \mathrm{dL}$. There was no significant difference in the blood profile of green sea turtles with or without fibropapillomatosis. The blood profile of green sea turtle with fibropapillomatosis is in the normal range

Keywords: erythrocyte; fibropapillomatosis; blood profile; green sea turtle

\section{PENDAHULUAN}

Perairan laut Indonesia kaya akan keanekaragaman satwa laut salah satu di antaranya adalah penyu. Di Indonesia terdapat enam spesies penyu dari tujuh spesies penyu yang ada di dunia ini di antaranya, yaitu penyu hijau (Chelonia mydas), penyu lekang (Lepidochelys olivacea), penyu tempayan (Caretta caretta), penyu sisik (Eretmochelys imbricate), penyu belimbing (Dermochelys coriacea) dan penyu pipih (Natator depressus) (Adnyana, 2009). Semua spesies penyu yang ada di dunia saat ini berada dalam daftar hewan terancam punah. Status terancam punah ini disebabkan oleh beberapa faktor, seperti pemanfaatan penyu untuk konsumsi, cinderamata, perdagangan, obat-obatan dan kegiatan adat masyarakat (Firliansyah, 2017).

Di Bali temuan kasus penyelundupan penyu pernah terjadi, terakhir tercatat tahun 2019 pada bulan Oktober ditemukan 18 penyu hijau yang ditangani oleh Polsek Kuta. Beberapa dari penyu hijau ini mengalami fibropapillomatosis. Fibropapillomatosis adalah tumor yang ditemukan pada semua spesies penyu, tetapi paling banyak ditemukan pada penyu hijau (Borrowman, 2008). Fibropapillomatosis dapat diidentifikasi pada penyu dengan adanya lesi fibroepitel jinak tunggal atau multiple. Lesi kulit biasanya terdapat pada jaringan lunak eksternal penyu, tetapi dapat tumbuh pada karapas, plastron, dan kornea penyu (Mannette, 2017)

Pemeriksaan hematologi dapat dijadikan metode pendukung diagnostik, dengan melihat adanya kenaikan atau penurunan jumlah sel darah (Reséndiz et al., 2018) yang meliputi total eritrosit, kadar hemoglobin dan nilai hematokrit. Dengan mengetahui gambaran darah penyu hijau dengan atau tanpa fibropapillomatosis, diharapkan dapat dijadikan acuan tindakan penanganan sesuai hasil temuan baik ada atau tidaknya fibropapillomatosis pada penyu hijau

\section{METODE PENELITIAN}

\section{Objek Penelitian}

Objek dari penelitian ini adalah penyu hijau (Chelonia mydas) yang disita oleh Polsek Kuta, Badung, Bali. Total sampel yang diambil adalah 10 sampel, diantaranya lima penyu hijau dengan fibropapillomatosis dan lima penyu hijau tanpa fibropapillomatosis.

\section{Pengukuran Morfometri, Diameter Tumor, dan Pemeriksaan Fisik}

Status kesehatan dan umur penyu hijau yang menjadi sitaan Polsek Kuta ditentukan dari hasil pengukuran morfometri. Morfometri penyu yang diukur meliputi straight carapace length (SCL) dan curved carapace length (CCL) (Borrowman, 2008). Selanjutnya dilakukan inspeksi terhadap ada tidaknya tumor, luka terbuka maupun abnormalitas pergerakan (Fong, 2010). Penyu yang dalam keadaan fibropapillomatosis diukur diameter tumor menggunakan jangka sorong dengan satuan centimeter (Zwarg, 2014).

\section{Pengambilan Sampel}

Sampel darah diambil dari lima penyu hijau dengan fibropapillomatosis dan lima penyu tanpa fibropapillomatosis. Penyu diposisikan dalam keadaan tengkurap atau ventral recumbency dengan kepala dan leher dipertahankan dalam keadaan terekstensi (Agustina, 2020). Sampel darah penyu hijau diambil sebanyak $3 \mathrm{~mL}$ melalui sinus servikal dorsal (vena jugularis) (Gunawan, 2020) menggunakan spuit $5 \mathrm{~mL}$ (March, 2018) dengan jarum berukuran 22 G (Fong, 2010). Sampel darah dipindahkan ke vacutainers steril yang mengandung lithium heparin (March, 2018). 


\section{Pemeriksaan Sampel Darah}

Total eritrosit dihitung dengan menggunakan hemositometer. Langkah pertama yang dilakukan ialah memasukkan sampel darah ke dalam pipet thoma eritrosit dengan cara diisap menggunakan aspirator sampai batas skala 0,5 pada pipet thoma eritrosit kemudian ditambahkan larutan Hayem sebagai pengencer sampai batas skala 101. Setelah itu dihomogenkan dan dibuang 3-5 tetes kemudian larutan yang sudah homogen tersebut diteteskan ke dalam kamar hitung. Selanjutnya diamati di bawah mikroskop cahaya dengan perbesaran 40 kali. Penghitungan butir eritrosit dilakukan pada lima kotak yang terletak diagonal pada lima bujur sangkar besar di tengah kamar hitung dengan cara mengalikan jumlah total eritrosit yang diperoleh dengan volume kamar hitung dan faktor pengencer (Nardini et al. 2013).

Sel darah yang berada pada lima bidang sesuai daerah yang berwarna merah dihitung kemudian jumlahnya, menurut Tsai et al. (2014) dan dimasukkan ke dalam rumus

$\operatorname{RBC}\left(10^{6} / \mu \mathrm{L}\right)=\mathrm{N} \times$ (volume chamber $\mathrm{x}$ pengenceran $)^{-1}$.

$$
\frac{\mathrm{N}}{\text { volume chamber } x \text { pengenceran }}
$$

Penentuan nilai hematokrit atau Packed Cell Volume (PCV) dilakukan dengan metode mikrohematokrit, menggunakan pipet mikrohematokrit dengan panjang $7 \mathrm{~cm}$ dan diameter 0,1 $\mathrm{mm}$. Darah dengan antikoagulan dimasukkan ke dalam pipet mikrohematokrit sekitar 6/7 bagian pipet. Tutup ujung masuknya darah dengan penutup khusus atau dengan menggunakan malam. Letakkan pipet hematokrit pada alat pemusing mikrohematokrit (microhematocrit centrifuge) (Dharmawan, 2002). Sentrifugasi dengan mesin sentrifugasi kecepatan $12.000 \mathrm{rpm}$ selama 5 menit (Stacy, 2018), hasilnya dibaca dengan microhematocrit reader.

Kadar hemoglobin dihitung dengan menggunakan hemometer Sahli. Masukkan $\mathrm{HCl}$ 0,1 N ke dalam tabung Sahli sampai skala 10 (Sari, 2016). Sediaan darah diisap menggunakan pipet Sahli dan aspirator sampai batas skala 20 $\mathrm{mm}^{3}$ kemudian dimasukkan ke dalam tabung Sahli yang telah terisi asam klorida. Dari campuran tersebut, terbentuk reaksi kimia yang menimbulkan warna coklat gelap yang merupakan reaksi perubahan hemoglobin dalam darah menjadi asam hematin (Amin, 2014).
Menurut Dharmawan (2002), penentuan nilai indeks eritrosit digunakan rumus sebagai berikut: MCV (fL) $=[\mathrm{PCV}(\%) \mathrm{x}$ (jumlah eritrosit $\left.\left(10^{6} \mu \mathrm{L}\right)^{-1}\right] \times 10 ; \mathrm{MCH}(\mathrm{pg})=[\mathrm{Hb}(\mathrm{g} / \mathrm{dL}) \times($ jumlah eritrosit $\left.\left(10^{6} \mu \mathrm{L}\right)^{-1}\right] \times 10 ;$ dan $\mathrm{MCHC}=[\mathrm{Hb}(\mathrm{g} /$ $\left.\mathrm{dL}) \times(\mathrm{PCV}(\%))^{-1}\right] \times 10$.

\section{Analisis Data}

Gambaran profil hematologi darah dua kelompok sampel yang dibagi berdasarkan ada tidaknya fibropapillomatosis dianalisis secara deskriptif, hasilnya disajikan dalam bentuk rataan \pm simpangan baku. Data kuantitatif yang diperoleh dari pemeriksaan total eritrosit, kadar $\mathrm{Hb}, \mathrm{PCV}$, dan indeks eritrosit, selanjutnya dianalisis menggunakan uji-t tidak berpasangan dan data diolah dan disajikan menggunakan program Statistical Product and Service Solutions (SPSS) Versi 25.0.

\section{Lokasi dan Waktu Penelitian}

Koleksi serta pemeriksaan sampel dilakukan di Turtle Conservation and Education Center (TCEC) di Pulau Serangan, Denpasar, Bali. Waktu penelitian selama empat minggu, yaitu pada bulan Desember 2019-Januari 2020.

\section{HASIL DAN PEMBAHASAN}

Hasil penelitian lima penyu hijau dengan fibropapillomatosis (FP) memiliki berat badan dengan rerata $30,8 \mathrm{~kg}$, dengan kisaran antara 11,3-59,7 kg. Rerata panjang lurus karapasnya (straight carapace length/SCL) adalah $60,8 \mathrm{~cm}$, dengan kisaran antara 43,3-80,3 cm, serta rerata panjang lengkung karapasnya (curve carapace length /CCL) adalah 65,4 cm, dengan kisaran antara 47-86 cm. Sementara itu, lima penyu hijau tanpa FP memiliki berat badan dengan rerata $74,6 \mathrm{~kg}$, dengan kisaran antara 10,5-129 $\mathrm{kg}$. Rerata panjang SCL adalah $74,3 \mathrm{~cm}$, dengan kisaran 44,3-96,5 cm. Rerata CCL adalah 75,6 $\mathrm{cm}$, dengan kisaran 48-103 cm. Inspeksi pada seluruh sampel tidak menunjukkan adanya luka terbuka maupun abnormalitas pergerakan.

Inspeksi terhadap kelima sampel penyu hijau dengan FP menunjukkan adanya tumor pada area bahu, di sekitar mata, dan di sekitar kloaka. Tumor berukuran antara 0,3-2,4 cm, dengan rerata $0,9 \mathrm{~cm}$.

Ringkasan data gambaran darah penyu hijau dengan atau tanpa FP disajikan dalam Tabel 1. Dari seluruh parameter yang diteliti, kelima sampel penyu hijau dengan FP memiliki 
rerata total eritrosit $0,55 \times 10^{6} / \mu \mathrm{L}$, dengan kisaran antara 0,31-0,80 x 10\%/ $\mathrm{L}$. Nilai PCV ditemukan berkisar antara $28-34 \%$, dengan rerata $31,40 \pm 2,3 \%$. Rerata kadar hemoglobinnya adalah 7,3 g/dL, dengan kisaran antara $6-8,8 \mathrm{~g} / \mathrm{dL}$. Sementara itu, rerata indeks eritrosit meliputi MCV, MCH, dan MCHC, secara berurutan ditemukan $616,7 \mathrm{fl}, 140,4 \mathrm{pg}$, dan 23,1 g/dL. Kisaran MCV, MCH, dan MCHC pada penyu dengan FP, secara berurutan ditemukan antara 427,7-903,2 fl; 110,7-193,5 pg dan 21,2$25,9 \mathrm{~g} / \mathrm{dL}$.
Gambaran darah kelima sampel penyu hijau tanpa FP memiliki rerata total eritrosit 0,45 x $10^{6} / \mu \mathrm{L}$, dengan kisaran antara $0,18-0,65 \times 10^{6} /$ $\mu \mathrm{L}$. Nilai PCV ditemukan berkisar antara 28$30 \%$, dengan rerata $29 \%$. Rerata kadar hemoglobinnya adalah $7,1 \mathrm{~g} / \mathrm{dL}$, dengan kisaran antara 6,1-8,2 g/dL. Sementara itu, rerata indeks eritrosit meliputi $\mathrm{MCV}, \mathrm{MCH}$, dan MCHC, secara berurutan ditemukan 784,7 fl, 191,9 pg, dan 24,4 g/dL. Kisaran MCV, MCH, dan MCHC pada penyu tanpa FP, secara berurutan ditemukan antara 446,1-1657,4 fl;

Tabel 1. Gambaran darah penyu hijau (Chelonia mydas) dengan atau tanpa fibropapillomatosis

\begin{tabular}{|c|c|c|c|c|}
\hline \multicolumn{5}{|c|}{ Seluruh sampel $(n=10)$} \\
\hline Variabel & Ada tidaknya FP & $\begin{array}{c}\text { Rataan } \pm \text { Simpangan } \\
\text { Baku }\end{array}$ & Rentangan & $\begin{array}{c}\text { Referensi (Kisaran } \\
\text { Normal) }\end{array}$ \\
\hline \multirow{4}{*}{$\begin{array}{l}\text { Total Eritrosit } \\
\left(\mathrm{x} 10^{6} \mu \mathrm{L}\right) \\
\text { PCV }(\%)\end{array}$} & Ada & $0,55 \pm 0,17$ & $0,31-0,80$ & \multirow[t]{2}{*}{$0,21-0,97^{\mathrm{c}}$} \\
\hline & Tidak & $0,46 \pm 0,18$ & $0,18-0,65$ & \\
\hline & Ada & $31,4 \pm 2,3$ & $28-34$ & \multirow[t]{2}{*}{$23-45^{\mathrm{c}}$} \\
\hline & Tidak & $29 \pm 0,71$ & $28-30$ & \\
\hline \multirow[t]{2}{*}{$\mathrm{Hb}(\mathrm{g} / \mathrm{dL})$} & Ada & $7,3 \pm 1,01$ & $6-8,8$ & \multirow[t]{2}{*}{$6,8-9,8^{\mathrm{a}}$} \\
\hline & Tidak & $7,1 \pm 0,75$ & $6,1-8,2$ & \\
\hline \multirow[t]{2}{*}{$\operatorname{MCV}(\mathrm{fl})$} & Ada & $616,7 \pm 176,9$ & $427,7-903,2$ & \multirow{2}{*}{$319,59-1428,57^{\mathrm{c}}$} \\
\hline & Tidak & $784,7 \pm 495,1$ & $446,1-1657,1$ & \\
\hline \multirow[t]{2}{*}{$\mathrm{MCH}(\mathrm{pg})$} & Ada & $140,4 \pm 31,3$ & $110,7-193,5$ & \multirow[t]{2}{*}{$156,8-357,9^{\mathrm{a}}$} \\
\hline & Tidak & $191,9 \pm 123,9$ & $107,7-411,4$ & \\
\hline \multirow[t]{2}{*}{$\mathrm{MCHC}(\mathrm{g} / \mathrm{dL})$} & Ada & $23,1 \pm 1,9$ & $21,2-25,9$ & \multirow[t]{2}{*}{$21-34,5^{\mathrm{b}}$} \\
\hline & Tidak & $24,4 \pm 1,9$ & $21,8-27,3$ & \\
\hline
\end{tabular}

Keterangan: a Aguirre, (1995), 'Samour (1998), ' ${ }^{\mathrm{b}}$ Suarez (2016); PCV= Packed Cell Volume; Hb= Haemoglobin; MCV= Mean Corpuscullar Volume; $\mathrm{MCH}=$ Mean Corpuscullar Haemoglobin; $\mathrm{MCHC}=$ Mean Corpuscullar Haemoglobin Concentration

Tabel 2. Uji-t tidak berpasangan gambaran darah penyu hijau (Chelonia mydas) dengan atau tanpa fibropapillomatosis

\begin{tabular}{lcc}
\hline & Seluruh sampel $(\mathrm{n}=10)$ & \\
\hline Variabel & Ada Tidaknya FP & Sig.(2-tailed) \\
\hline Total Eritrosit & Ada & $\mathrm{P}=0,423$ \\
$\mathrm{PCV}$ & Tidak & $\mathrm{P}=0,079$ \\
$\mathrm{Hb}$ & Ada & $\mathrm{P}=0,757$ \\
$\mathrm{MCV}$ & Tidak & $\mathrm{P}=0,507$ \\
$\mathrm{MCH}$ & Tida & $\mathrm{P}=0,413$ \\
$\mathrm{MCHC}$ & Ada & $\mathrm{P}=0,315$ \\
\hline
\end{tabular}

Keterangan : MCV (Mean Corpuscullar Volume), MCH (Mean Corpuscullar Haemoglobin), MCHC (Mean Corpuscullar Haemoglobin Concentration). 
107,7-411,4 pg dan 21,8-27,3 g/dL.

Hasil uji-t tidak berpasangan penyu hijau dengan atau tanpa FP sebanyak 10 sampel disajikan dalam Tabel 2. Gambaran darah antara penyu dengan FP ataupun tanpa FP tidak berbeda nyata $(P>0,05)$. Nilai total eritrosit dari penelitian ini berada dalam rentang nilai yang disampaikan oleh Suarez et al. (2016) yang berkisar antara 0,21-0,9 x106 $\mu \mathrm{L}$, dan penelitian yang dilakukan oleh Reséndiz (2018), sehingga dikonfirmasi tidak mengalami anemia seperti yang dilaporkan oleh Adnyana (1997), dan Zwarg (2014). Penyu dengan FP parah cenderung menjadi anemik, dibandingkan dengan penyu tanpa FP atau penyu dengan FP yang kurang parah (Work dan Balazs, 1999; Kang, 2007). Berdasarkan data dari penelitian ini, penyu dengan FP tidak menunjukkan anemia, karena kondisi tumor yang belum parah dan tidak ditemukan pendarahan (Adnyana, 1997). Selain itu, FP yang ditemukan tidak tumbuh pada jaringan hemopoetik yang dapat mengganggu proses pembentukan eritrosit. Faktor yang memengaruhi total eritrosit adalah musim. Perubahan musim memiliki efek signifikan pada nilai hematologi, terutama pada musim panas yang memiliki total eritrosit lebih tinggi (Zhang, 2011).

Dari hasil penelitian ini, nilai PCV pada penyu hijau dengan FP tidak mengalami penurunan. Rata-rata nilai PCV dari keseluruhan sampel penyu hijau dari hasil penelitian ini mirip dengan penelitian yang dilakukan oleh Kang (2007) yang berkisar antara $25-49 \%$ pada penyu hijau yang berasal dari Culebra, Puerto Rico, dan Suarez et al. (2016) yang berkisar antara 23-45\% pada penyu hijau yang berasal dari Peru. Nilai PCV dipengaruhi oleh ukuran tumor, semakin besar diameter tumor, maka semakin kecil nilai PCV (Work dan Balazs, 1999). Kisaran kadar Hb dari seluruh sampel penelitian berada dalam rentang nilai yang disampaikan oleh Samour (1998) yang berkisar antara 5,3-12,4 g/dL. Kadar $\mathrm{Hb}$ penyu hijau dengan FP tidak menunjukkan adanya penurunan, seperti yang disampaikan oleh Aguirre (1995) pada penyu hijau dengan FP memiliki kadar $\mathrm{Hb}$ yang signifikan rendah dari penyu hijau tanpa FP, yang menunjukkan bahwa penyu hijau mengalami anemia nonregeneratif dan dalam kondisi kronis.

Nilai PCV, kadar hemoglobin, dan total eritrosit digunakan untuk menentukkan indeks eritrosit. Analisis statistika untuk semua indeks eritrosit adalah tidak berbeda nyata $(\mathrm{P}>0,005)$.
Rerata nilai MCV dari penelitian ini berada dalam rentang nilai yang disampaikan oleh Samour (1998) yang berkisar antara 601,61446,4 fl, dan Suarez et al., (2016) yang berkisar antara 319,6-1428,6 fl. Sementara itu, rerata nilai MCHC yang diperoleh dari penelitian ini berada dalam rentang nilai yang disampaikan oleh Samour (1998) yang berkisar antara 20-32 $\mathrm{g} / \mathrm{dL}$. Rerata nilai MCH pada penelitian ini, masuk ke dalam rentangan $\mathrm{MCH}$ dari penelitian Aguirre (1995) yang berkisar antara 156,8-357,9 pg. Penentuan nilai MCV berguna untuk menentukan jenis anemia berdasarkan ukuran rata-rata eritrosit, yaitu anemia mikrositik, normositik, atau makrositik. Nilai MCHC berguna untuk menentukan jenis anemia berdasarkan kadar hemoglobin dalam satu eritrosit, yaitu anemia hipokromik, hiperkromik, atau normokromik (Agustina, 2020). Peningkatan nilai MCV dan MCHC dapat menyebabkan anemia makrositik, dan penurunan nilai MCV dan MCHC menyebabkan anemia mikrositik (Thrall, 2004 ; Zwarg, 2014). Nilai $\mathrm{MCH}$ yang rendah menunjukkan kurangnya hemoglobin pada hewan yang terkena penyakit, yang mungkin mengakibatkan kekurangan oksigen pada jaringan (Zwarg, 2014) dan menyebabkan anemia hipokromik. Pada anemia hiperkromik terjadi peningkatan MCH (Reséndiz, 2018b).

\section{SIMPULAN}

Berdasarkan penelitian yang dilakukan dapat disimpulkan bahwa gambaran darah penyu hijau dengan atau tanpa fibropapillomatosis adalah sama. Gambaran darah penyu hijau dengan fibropapillomatosis pada penelitian ini memiliki rata-rata total eritrosit 0,55 x $10^{6} / \mu \mathrm{L}, \mathrm{PCV} 31,4 \%$, hemoglobin 7,2 g/dL, serta indeks eritrosit MCV 616,7 fl, MCH 140,4 pg, dan MCHC 23,1 g/dL. Gambaran darah dari penyu hijau tanpa fibropapillomatosis memiliki rata-rata total eritrosit $0,46 \times 10^{6} / \mu \mathrm{L}$, PCV 29\%, hemoglobin $7,1 \mathrm{~g} / \mathrm{dL}$, serta indeks eritrosit meliputi MCV 784,7 fl, MCH 191,9 pg, dan MCHC 24,4 g/dL.

\section{SARAN}

Penelitian lebih lanjut perlu dilakukan, terkait dengan ukuran tumor dan jumlah sampel yang lebih banyak. 


\section{UCAPAN TERIMA KASIH}

Penulis mengucapkan terima kasih kepada pihak Turtle Concervation and Education Center (TCEC), Serangan, Bali atas bantuannya dalam penelitian ini. Terima kasih penulis sampaikan kepada para pihak yang telah membantu penulisan artikel ini.

\section{DAFTAR PUSTAKA}

Adnyana W, Ladds PW, Blair D. 1997. Observations of Fibropapillomatosis in Green Turtles (Chelonia mydas) in Indonesia. Aust Vet J 75(10): 737-742.

Adnyana, I.B.W., Hitipeuw, C., 2009. Panduan Melakukan Pemantauan Populasi Penyu di Pantai Peneluran di Indonesia. Jakarta. WWF Indonesia Marine Program. Hlm. 23

Aguirre AA, Balazs GH, Spraker, TR Gross TS. 1995. Adrenal and hematological responses to stress in juvenile green turtles (Chelonia mydas) with and without fibropapillomas. Physiological Zoology 68: 831-854.

Agustina LA, Dharmawan NS, Adnyana IBW. 2020. Hematological Profiles of Green Sea Turtle (Chelonia mydas) Rehabilitated at Turtle Conservation and Education Center, Serangan Island, Denpasar, Bali. Jurnal Veteriner. 21(1): 14 -23.

Amin WAA. 2014. Profil Eritrosit dan Leukosit pada Ular Sawah (Ptyas korros). Bogor. Institut Pertanian Bogor. Hlm. 1-22.

Borrowman K.M. 2008. Prevalence And Severity of Fibropapillomatosis. Dalam. Juvenile Green Turtles (Chelonia Mydas) In Three Habitats on Florida's East Coast. B.S. Florida Institute of Technology. Hlm. 1-59.

Dharmawan NS. 2002. Pengantar Patologi Klinik Veteriner Hematologi Klinik. Denpasar. Universitas Udayana. Hlm. 2944.

Firliansyah E, Kusrini MD, Sunkar, A. 2017. Pemanfaatan dan Efektivitas Kegiatan Penangkaran Penyu di Bali bagi Konservasi Penyu. J Trop Biodiv Biotech 2: 21-27.

Fong CL, Chen HC, Cheng IJ. 2010. Blood Profiles from Wild Populations of Green Sea
Turtles in Taiwan. Journal of Veterinary Medicine and Animal Health 2(2): 8-10.

Gunawan IWNF, Maslim AL, Adnyana, IBW, Dharmayudha AAGO, Sudimartini LM. 2020. The Differences of Ultrasonography Imaging Between Green Turtles (Chelonia mydas) and Olive Ridley Turtles (Lepidochelys olivacea) in Bali. Jurnal Veteriner. 21(1): 124-135.

Kang KI. 2007. Pathological Evaluation of Fibropapillomatosis In Green Sea Turtles: Evaluation of Blood Parameters and Localization of Virus In Tumors, As Determined By In Situ Hybridization. Georgia. University of Georgia. Hlm. 1-72.

Mannette, M.C., Philips, A.C.N. 2017. Occurrence of Fibropapilloma Tumours on Green Sea Turtles, Chelonia mydas in Trinidad, West Indies. Journal of the Trinidad and Tobago Field Naturalists' Club.14-20.

March DT, Herrin KV, Peters A, Ariel E, Blyde D, Hayward D, Christidis L, Kelaher BP. 2018. Hematologic and biochemical characteristics of stranded green sea turtles. Journal of Veterinary Diagnostic Investigation. 30(3): 423-429.

Nardini G, Leopardi S, Bielli M. 2013. Clinical hematologi in reptilian species. Vet Clin Exot Anim. 16: 1-30.

Reséndiz E, Fernández-Sanz H, Ramos D, Silva VL, Lara-Uc MM. 2018. Condition and Haematological Values of Free-Ranging Eastern Pacific Green Turtles (Chelonia mydas) from Baja California Sur, Mexico. SM J Clin Pathol 3(1): 10-16.

Reséndiz E, Lara-Uc MM. 2018b. Health Assessments in Free-Ranging Sea Turtles: Perspective of Animal Welfare in Wildlife. Hlm. 29-49.

Samour JH, Howlett JC, Silvanose C, Hasbun CR, A1-Ghais SM. 1998. Normal Haematology of Free-Living Green Sea Turtles (Chelonia mydas) from the United Arab Emirates. Comparative Haematology International 8: 102-107.

Sari Y, Tjong DH, Rahayu R. 2016. Gambaran Darah Katak Fejervarya limnocharis di Lahan Pertanian yang Menggunakan Pestisida di Sumatera Barat. Biogenesis Jurnal Ilmiah Biologi. 4(2): 115-121 
Stacy NI, Lynch JM, Arendt MD, Avens L, Braun, McNeill J, Cray C, Larisa A, Day RD, Harms CA. Michelle L, Margie MPA, Kelly T, Segars AL, Norton TM. 2018. Chronic debilitation in stranded loggerhead sea turtles (Caretta caretta) in the southeastern United States: Morphometrics and clinicopathological findings. PLoS ONE 13(7): e0200355.

Suarez YT, Montes D, Zuñiga IR, Mangel JC, Alfaro-Shigueto J. 2016. Hematologic, morphometric, and biochemical analytes of clinically healthy green sea turtles (Chelonia mydas) in Peru. Chelonian Conservation and Biology 15(1): 153-157.

Tsai C, Yu J, Wang Y, Fan P, Cheng T, Wang L. 2014. An alternative staining method for counting red-eared slider turtle (Trachemys scripta) blood cells using crystal violet in cells diluted with $0.45 \%$ sodium chloride. Journal of Veterinary Diagnostic Investigation 26(5): 610-615.
WorkTM, Balazs GH. 1999. Relating Tumor Score to Hematology in Green Turtles with Fibropapillomatosis in Hawaii. Journal of Wildlife Diseases 35(4): 804-807.

Zhang F, Gu H, Li P. 2011. A Review of Chelonian Hematology. Asian Herpetological Research 2(1): 12-20.

Zwarg T, Rossi S, Sanches TC, Cesar M de O, Werneck MR, Matishima ER. 2014. Hematological and histopathological evaluation of wildlife green turtles (Chelonia mydas) with and without fibropapilloma from the north coast of São Paulo State, Brazil. Pesquisa Veterinária Brasileira 34(7): 682-688. 